\title{
Rontgen, rad en gray - merktekens in de radiotherapie
}

Citation for published version (APA):

Keijser, A. H. (1983). Rontgen, rad en gray - merktekens in de radiotherapie. Maastricht University. https://doi.org/10.26481/spe.19830902ak

Document status and date:

Published: 02/09/1983

DOI:

10.26481/spe.19830902ak

Document Version:

Publisher's PDF, also known as Version of record

\section{Please check the document version of this publication:}

- A submitted manuscript is the version of the article upon submission and before peer-review. There can be important differences between the submitted version and the official published version of record.

People interested in the research are advised to contact the author for the final version of the publication, or visit the DOI to the publisher's website.

- The final author version and the galley proof are versions of the publication after peer review.

- The final published version features the final layout of the paper including the volume, issue and page numbers.

Link to publication

\footnotetext{
General rights rights.

- You may freely distribute the URL identifying the publication in the public portal. please follow below link for the End User Agreement:

www.umlib.nl/taverne-license

Take down policy

If you believe that this document breaches copyright please contact us at:

repository@maastrichtuniversity.nl

providing details and we will investigate your claim.
}

Copyright and moral rights for the publications made accessible in the public portal are retained by the authors and/or other copyright owners and it is a condition of accessing publications that users recognise and abide by the legal requirements associated with these

- Users may download and print one copy of any publication from the public portal for the purpose of private study or research.

- You may not further distribute the material or use it for any profit-making activity or commercial gain

If the publication is distributed under the terms of Article $25 \mathrm{fa}$ of the Dutch Copyright Act, indicated by the "Taverne" license above, 


\section{Röntgen, rad en gray \\ Merktekens in de radiotherapie}

Rede uitgesproken bij de aanvaarding van het ambt van hoogleraar in de radiotherapie aan de Rijksuniversiteit Limburg op vrijdag 2 september 1983 door Dr. A. H. Keijser. 

Dames en Heren Leden van het Universiteitsbestuun,

Dames en Heren Leden van de Universiteitsraad,

Dames en Heren Hoogleraren, Docenten en Leden van de Wetenschappelijke Staí,

Dames en Heren Studenten

en voorts gij allen die door uw aanwezigheid blikk geeft wan uw belangstelling,

Zeer gewaardeerde toehoorders,

$\cup$ kent de geschiedenis. In 1895 ontdekte Röntgen de door hem genoemde X-stralen. Van Becquerel zijn de proeven die in $1896 \mathrm{de}$ radio-activiteit van uranium aantoonden en het echtpaar Curie identificeerde enkele jaren later de elementen radium en polonium.

Door deze vondsten werd een periode ingeluid, die voor de geneeskunde van niet te schatten belang zou blijken te zijn. Toch duurde het tot 1908 voor Rutherford als eerste een studie publiceerde over het door de gevonden elementen en X-straling opgewekte fenomeen van de ionisatie. Hierbij worden ionen gevormd die een verstoring geven van de normale stofwisseling in en om de cel en wel in die mate, dat er geen celdeling meer mogelijk is met als gevolg het afsterven van de bestraalde cellen. Het doel van de radiotherapie is dit op een zodanige wijze te doen, dat het gezonde weefsel wordt gespaard of het vermogen tot herstel behoudt.

Aanvankelijk werd er wel een effect van stralling op het menselijk lichaam waargenomen, doch het zou jaren duren alvorens men voldoende kennis kon vergaren die inzicht zou geven in de wijze waarop de ionisatie inwerkt op de gezonde en de zieke lichaamscel. Pas veel later zou bliken dat ionisatie van het DNA in de celkern de voomaamste oorzaak is voor het effect van straling op gezond of kwaadaardig weefsel.

Door Bequerel worden waamemingen gedaan over het effect van radium op de huid en $A$ lbers-Schönberg past röntgenstraling toe op dieper gelegen delen van het lichaam. Hij stelde verschil in gevoeligheid vast voor diverse weefsels en legt hierbij de experimentele basis voor hetgeen door Bergonié en Tribandeau later 
in een naar hen genoemde wet zou worden vastgelegd, namelijk dat. straling effectiever is naarmate het reproductieve vermogen van de cellen groter is, het delingsproces langer duurt en de bouw en de functie van de cellen minder gedifferentieerd is.

Met de door Coolidge ontwikkelde bestralingsbuis konden dusdlanige hoge spanningen worden opgewekt, dat het mogelijk bleek de hierbij geproduceerde röntgenstraling voor therapeutische doeleinden te gebruiken. De mogelijkheid om röntgenstraling met een energie van 200 a $300 \mathrm{kV}$ in een praktisch hanteerbaar apparaat op te wekken luidde het tijdperk van de orthovoltbestraling in, een periode die van de jaren 20 tot ruim na de 2e wereldoorlog zou duren.

Ik heb u slechts enkele gegevens uit de boeiende geschiedenis van het prille begin van de radiotherapie willen noemen, om te komen tot het voor ons betoog belangwekkende eerste merkteken.

\section{Röntgen}

In de eerste jaren van de radiotherapie liet men zich wat betreft de dosering in de eerste plaats leiden door het optreden van het beoogde resultaat. Meestal was dit een verkleinen of verdwijnen van het bestraalde gezwel. Ook maakte men gebruik van hetgeen wij thans noemen een biologische standaard. Een bekend voorbeeld hiervan is de huiderycheemdosis, een rode verkleuring van de huid na een enkele dosis röntgenstraling van $200 \mathrm{kV}$, indien deze op een oppervlakte van $70 \mathrm{~cm}^{2}$ wordt gegeven en in $80 \%$ van de gevallen binnen 30 dagen optreedt.

Het is duidelijk dat dergelijke biologische wijze van dosisbepaling een grote mate van onnauwkeurigheid inhoudt. Het biologische object immers, dat als standaard moet dienen, kent op zich al vele variaties. Het was dan ook een belangrijke verbetering voor de toepassing van reproduceerbare exacte stalingsdoses dat een in 1925 opgerichte internationale commissie van stralingseenheden, de ICRU, in 1928 de definitie röntgen heeft ingevoerd. Het ligt butten het kader van deze les dieper in te gaan op de fysische aspecten van deze stralingsgrootheid, die overigens in 1937 door genoemde commissie werd herzien. Voor ons is de kennis van betang dat het bij de " $r$ "gaat om een dosis ioniserende straling, vij in lucht gemeten. Een bepaling van ionisatie in lucht geeft echter onvoldoende inzicht in de mate van ionisaties in weefsel, in het gezwel, in de kankercel, het DNA van de celkern. De door de ICRU in 1956 voorgestelde definitieve eenheid " $R$ " maakt dit bezwaar niet ongedaan. 
De radiotherapie ontwikkelde zich in de periode van de jaren 40 tot een discipline, die geleidelijk zich een zelfstandige plaats ging verwerven bij de behandeling van verschillende ziekten. Aarvankelijk werden zowel aandoeningen van goedaardige of benigne aard bestraald, als kwaadaardige, maligne afwijkingen. Na de jaren 40 werd het indicatiegebied voor benigne afwijkingen kleiner, omdat meer inzicht werd verkregen in de schadelijke effecten van ioniserende straling. Men trachtte door het gebruik van diverse technieken het gezonde weefsel zoveel mogelijk te sparen en voorkwam in de meeste gevallen schade hiervan. De ongunstige neveneffecten werden geaccepteerd voor zover afgewogen tegen de gunstige resultaten in de worm wan een genezing van een kwaadaardige ziekte. Vanuit de optiek van de radiodiagnostiek is onlangs door mijn leermeester Penn in zijn afscheidscollege hierop dieper ingegaan. Geleidelijk wordt in deze tijd de indicatie woor bestraling van goedaardige aandoeningen vrijwel geheel verlaten.

Wij spraken van de radiotherapie als zelfstandige discipline. Dit is juist waar het betreft een eigen verantwoordelijkheid van de radiotherapeut bij indicatie en uitvoering van de bestralingsbehandeling. Historisch gezien zijn het de snijdende specialismen, die eerst het kankerproces geheel of gedeeltelijk trachten te verwijderen. Van de radiotherapeut werd daarna verwacht de macroscopisch zichtbare of microscopisch vermoede rest te vernietigen. De rol van de chemotherapie komt pas later aan de orde. Op grond van ligging en grootte van niet operabele tumoren trachtte men deze door middel van vóórbestraling kleiner te maken en zodoende alsnog behandelbaar met chirurgie. Slechts bij stralengevoelige tumoren werd bestraling als enige modaliteit uitgevoerd. Tijdens de $2 \mathrm{e}$ wereldoorlog nam de ontwikkeling van de kernenergie een grote whicht Men bleek in staat van diverse stoffen radio-actieve isotopen te maken. Van belang voor de radiotherapie is het ter beschikking komen van het radio-actieve isotoop cobalt. Dit element wordt, na wegfilteren van de uitgezonden bèta-straling, als stralingsbron van gammastraling, een electro-magnetische straling met een energie van $1,2 \mathrm{MeV}$, dit wil zeggen $1200 \mathrm{keV}$, als cobaltstraler ontwikkeld. Het gebruik van deze vorm van hoogenergetische straling heeft de megavoltperiode ingeluid. De voordelen boven de orthovolt zijn werschillende. Door een speciale bij de hoge energie passende dosisverdeling in het te bestralen gebied, krijgt de huid een lagere dosis dan het er onder gelegen weefsel. Dit niet geheel terecht genoemde huidsparende effect - de huid immers krijgt wel een 
stralingsdosis, doch een lagere - mist men bij de orthovoltbestraling. Bij deze orthovoltbehandeling is de huidtolerantie vaak een beperkende factor om een voldoende hoge dosis in de dieper in het lichaam gelegen tumor te geven.

De niet onaanzienlijk grotere absorptie van orthovoltstraling in bot vergeleken met spier- en vetweefsel, is een andere factor waardoor een onvoldoende dieptedosis kan worden bereikt, een beperking welke het meest uitgesproken is op plaatsen waar skeletdelen de onderliggende weke delen beschermen, zoalls schedel en bekken. Bij cobaltstraling ontbreekt dit verschil in absorptie nagenoeg geheel, zodat men in dit verband van een botsparend effect spreekt. Hier geldt evenals bij de huid, dat ook deze sparing slechts een betrekkelijke is.

De onmogelijkheid om met orthovoltbestraling tot adequate dosering in diep in het lichaam gelegen gezwellen te komen, is wellicht de reden dat thans bij sommigen nog steeds de gedachten leeft dat adenocarcinomen en plaveiselcelcarcinomen van dieper gelegen organen, zoals alvleesklier, luchtpijp en maag-darmkanaal, niet of onvoldoende gevoelig zouden zijn voor ioniserende straling. Het gebruik van megavolttherapie gepaard met inzichten aangedragen door radiofysici en radiobiologen, hebben het tegendeel bewezen. Om een dosiseenheid te gebruiken die in overeenstemming is met de eerder genoemde absorptie van ioniserende straling in het weefsel in plaats van ionisatie in lucht, werd in 1953 de "rad" als eenheid van geabsorbeerde dosis ingevoerd. Wij hebben deze gebeurtenis als tweede merkteken van onze beschouwing over de radiotherapie willen aanhouden, niet zo zeer dat deze notitie wan dosis veel heeft veranderd in de radiotherapie, maar omdat in de jaren 50 er voor ons specialisme belangrijke ontwikkelingen optraden. Met deze eenheid van geabsorbeerde dosis is men zich gaan afvragen wat er nu precies met de tumorcel en de tumor gebeurt onder invloed van ioniserende straling.

\section{Rad}

Nadat de megavoltherapie voornamelijk in de vorm van een cobaltstraler in de radiotherapeutische centra gemeengoed was geworden, werd het aantal indicaties waarbij bestraling als enige behandeling van kanker werd gebruikt, groter. Op grond van nauwgezette klinische waarneming werden bestralingsschemata opgesteld, die tot steeds betere resultaten leidden. Het voert te ver de 
vele radiotherapeuten te noemen die in binnen- en buitenland hebben bijgedragen tot het opstellen van verschillende behandelingsvormen. Een uitzondering wil ik maken voor mijn leermeester Kok, die belangrijk werk heeft gedaan bij de bestudering van het effect op normaal weefsel bij bestraling van het larynxcarcinoom en borstkanker. Hij was het, die lang voordat het meerdere malen bestralen per dag als een nieuw schema in de belangstelling kwam, deze zogenaamde multifractionering reeds bij bepaalde vormen van hersentumoren toepaste.

Blikken wij wanaf dit tweede merkteken verder rond.

In 1956 ontwikkelden Puck en Marcus een techniek die het mogelijk maakt het vermogen van menselijke en dierlijke cellen tot ongelimiteerde proliferatie kwantitatief te bepalen. Door cellen onder diverse omstandigheden met verschillende doses te bestralen, is een schat aan gegevens verzameld. Deze kennis heeft echter niet geleid tot radicale veranderingen van de wijze van behandeling in de klinische radiotherapie, omdat het menselijk kankergezwel complex is samengesteld. Deze complexiteit betreft niet alleen de stadia warin de kankercellen verkeren, maar ook de relatie van het gezwel tot het normale weefsel die voor een miet onaanzienlijk deel bepaald wordt door de natuurlijke weerstand van het lichaam tegen het kankerproces en de bloedvatvoorziening van de tumor vooral het belang van de bloedvatvoorziening werd al spoedig onderkend. Bij een goede valatvoorziening van een tumor mag men een goede zuurstofvoorziening hiervan aannemen. Uit experimenten is gebleken dat een goed geoxygeneerde cel veel stralengevoeliger is dan een cel, die zich in een zuurstofarm milieu bevindt. De logische conclusie hieruit is, dat de bestraling het beste in zuurstofrijk milieu kan worden uitgevoerd. Er bestaat dan ook een grote mate van stralengevoeligheid van de goed geoxygeneerde tumor. In de kliniek heeft men bestraling met toedienen van extra zuurstof toegepast om een maximale zuurstofverzadiging en daardoor een goede stralengevoeligheid te bereiken. Dit op de theorie gebaseerde concept blijkt echter in de praktijk niet die resultaten te hebben gegeven, die men er van verwachtte. Het centrum van de tumor immers bestaat vaak uit een gebied waar zich geen bloedvaten bevinden, maar slechts dood, necrotisch weefsel en cellen die in een toestand van rust verkeren. Tevens heeft recent onderzoek aangetoond dat bloedvaten in een tumor vaak maximaal verwijd zijn en derhalve al voor een optimale bloedzuurstoftoevoer zorgen. Men tracht daarom vaatingroei in de tumor te bevorderen door het geven 
van bestraling met verschillende bestralingstracties over een langere periode. De goed yan zuurstof voorziene gezwelcellen aan de periferie varn de tumor zijn thet meest gevoelig woor bestraling en zullen derhalve bij relatief lage stralingsdoses afsterven. Hierdoor krijgen de bloedvaten gelegenheid van buitenaf de tumor in te groeien en de dieper in de tumor gelegen cellen beter van zuurstof te voorzien. Het gezwel zal door de bestraling als het ware worden afgeschild. Ook kan men gebruik maken van een zg. split-course bestraling. Bij deze vorm van behandeling wordt een periode van meestal 2 weken ingelast, waarbij er geen bestraling wordt toegepast. Volgens dit concept wordt aan de bloedvaten de gelegenheid gegeven in de door de bestraling kleiner geworden tumor in te groeien en zo de oxygenatie en daarmee de stralengevoeligheid te bevorderen. Ook zal men bij deze behandeling in sterkere mate dan dit bij de gewone fractionering het geval is, de gezwelcellen kunnen treffen in de gevoelige fase van de celcyclus. $1 \mathrm{k}$ kom hier direct op terug. Van groter belang echter lijkt het herstel van normale weefselschade bij de genoemde fractionering en split-course behandeling. De radiotherapeut zal gewapend met deze kennis en klinische ervaring moeten beslissen welke bestralingsschema hij voor de zich presenterende kankerpatiënt het beste vindt. Behalve het geschetste effect van reoxygenatie, zijn er een aantal radiobiologische principes waarvan ik slechts de door Withers genoemde " 4 r's van de radiobiologie" zou willen noemen.

Naast de reoxygenatie kent men de repair, de repopulatie en de redistributie. Repair houdt in dat na een bestralingsfractie er een herstel van schade kan optreden. Een bepaald aantal fracties van bepaalde grootte zal nodig zijn om de tumor effectief te kunnen bestrijden. Houden de cellen van nomaal of tumorweefsel tijdens een bestralingsbehandeling het vermogen om door te groeien dan spreekt men van repopulatie. Hiertoe rekent men tevens de migratie van tumorcellen van buiten het bestralingsveld. Bij de bespreking van oxygenatie duiden wij reeds aan dat cellen zich in verschillende fasen van ontwikkeling kunnen bevinden. Zonder diep in te gaan op de celkinetiek is woor het begrip redistributie het volgende van belang. Bij de meeste lichaamscellen onderscheidt men een aantal fasen waarin perioden van rust zich afwisselen met perioden van activiteit, nodig om te komen tot celdeling. De Co-fase is er een waarbij de cel zich in een toestand van rust bevindt. Deze fase wordt voorafgegaan door de delings of mitosefáse M. Voorts kent men de Gi en G2-fasen

( $G$ - gap), gedurende welke er verschillende vormen van metabolisme 
in cel en celkern optreden. De cellen waaruit weetsel is opgebouwd verkeren in verschillende fasen. Door bestraling zal de groei van dié cellen het eerst uitgeschakeld worden, die in de voor bestraling meest gevoelige periode werkeren, te weten de $\mathrm{M}$ of de C2-fase. Het zal enige tijd duren alvorens de cellen, die zich in een voor de bestraling minder gevoelige fase bevinden, zich tot gevoelige cellen hebben ontwikkeld. Behalve bij het reeds eerder genoemde belang voor het herstel van schade van normaal weefsel, speelt fractionering tevens een rol bij de geschetste redistributie. Men geeft in zo'n periode de cellen als het ware de tijd in voor bestraling gevoelige fasen te komen. Hoe de fractionering dit wil zeggen het geven van bestraling in een aantal zittingen uitgespreid over een of meer weken, precies dient te geschieden is vooralsnog voornamelijk een kwestie van ervaring. Van klinische en experimentele zijde erkent men de mogelijkheid om door variaties in fractioneringsschema en totale tijdsduur van de behandeling een groter differentieel effect te verkrijgen op tumor en gezond weefsel.

Enkele decennia nadat de rad als eenheid van straling was gedefiniëerd en ingevoerd, volgde een belangrijke ontwikkeling van de electronica. Zoals de ontwikkeling van de kernenergie het tijdperk van de cobaltstraler inluidde, zo werd in deze periode de lineaire versneller antwikkeld. Hiermee beschikken wij over een apparaat waarbij door bijzondere electronische schakelingen electronen zo worden versneld, dat röntgenstraling van hoge energie kan worden geproduceerd. In de medische praktijk worden foton-energieën van 4 tot $30 \mathrm{MV}$ gebruikt. Uit overwegingen van practische aard wordt geen hogere röntgenenergie gekozen. Enerzijds omdat bij deze hoogenergetische straling de dosisverdeling in het lichaam minder gunstig wordt en anderzijds omdat men te kampen krijgt met problemen van radio-actief worden van bestraalde objecten. Toch berust de aanschaf van deze geavanceerde apparatuur niet op prestige overwegingen. De lineaire versneller namelijk kan behalve als röntgenapparaat ook gebruikt worden als electronenstraler. Met electronenbestraling is het mogelijk scherp omschreven oppervlakkig gelegen delen van het lichaam te bestralen, omdat deze deeltjesstraling vrijwel volledig in de oppervlakte wordt geabsorbeerd. Een indicatie voor deze behandeling is onder meer de uitzaaiingen van kankercellen in oppervlakkig gelegen lymfklieren van hals en liezen. Een ander indicatiegebied is een kwaadaardige aandoening die zich tot de gehele huid uitstrekt, de mycosis fungoïdes. Vaak wordt hierbij de patiënt met een zogenaamde totale lichaamsbestraling behandeld. 


\section{Gray}

Ik zou vanuit een derde merkteken stil willen staan bij recente ontwikkelingen in de oncologie, die enerzijds beloften inhouden maar anderzijds ook speciale aandacht opeisen. Toen in 1987 in het kader van de internationale normalisatie van eenheden de "gray" $(1$ gray -1 Gy -100 rad) werd ingevoerd, waren er in de radiotherapie ontwikkelingen gaande om het effect op het kankerproces te versterken. Men tracht tegenwoordig met bestraling van 2 of meer fracties per dag een groter effect op de tumor te bereiken, bij een zo gering mogelijke invloed op het normale weefsel. De laatste jaren is veel klinisch onderzoek verricht met radiosensitizers, stoffen die het effect van de bestraling op tumorcellen in anoxemische toestand en in de ongevoelige fiase van de cyclus versterken. De toxiciteit van deze middelen voor de patiënt is echter vaak een belemmering voor een ruimere toepassing van deze middelen. Men zoekt naarstig naar stoffen die goed worden verdragen.

Tenslotte wil ik noemen de interactie van chemotherapie en radiotherapie. Ondanks het vele onderzoek dat bij proetdieren is verricht, ontbreekt het in veel gevallen in de kliniek aan goed toepasbare combinatieschema's. Zorgwekkend is dat men hier en daar een bedenkelijke ontwikkeling aantreft, waarbij de typische locale en loco-regionale behandeling, zoals chirurgie en radiotherapie, wordt vervangen door chemotherapie. Men ziet het uit de geschiedenis van de geneeskunde bekende fenomeen dat bij het optreden van nieuwe mogelijkheden deze aanvankelijk worden overgewaardeerd. De indruk bestaat dat dit bij de chemotherapie ook het geval is. Het gemak waarop men zich aan klinische experimenten waagt, zet vraagtekens bij het nut dat men de patiënt denkt te bieden. Ook ik erken en accepteer de spanningsvelden die bij ontwikkelingen in de geneeskunde kunnen ontstaan. Een vraagteken zou ik echter willen zetten bij het gemak waarbij een behandelingsvorm die zijn nut heeft bewezen, wordt verlaten. Een vraagteken past ook bij het gemak waarbij men kleine wijzigingen in chemotherapieschema's maakt en met slechts een klein aantal patiënten wil aantonen dat de overleving enkele weken, hooguit enkele maanden verbetert. Wat is de kost en wat is de baat voor patient en familie. Verheugend is de ontwikkeling in onze regio Midden- en ZuidLimburg, die de laatste jaren in toenemende mate een goede samenwerking laat zien tussen diegenen die zich met de behandeling van kankerpatiënten bezighouden. 
Bij alle instellingen van gezondheidszorg was de bereidheid tot samenwerking op het gebied van de kankerbehandeling dermate groot, dat er oncologische werkgroepen werden gevormd. Deze multidisciplinair samengestelde groepen maakten protocollen, waarin richtlinen woor diagnostiek, behandeling en nacontrole of follow-up voor verschillende vormen van kanker worden vastgelegd. Hierbij werd vooruitgelopen op de door de centrale overheid gepropageerde samenwerkingsverbanden. Formalisatie van deze groepen vond plaats door de oprichting in 1981 van het Integraal Kankercentrum Limburg, het I.K.L., dat tevens steun in onder andere materiële en financiële zin gaf. Een onlangs door het I.K.L. aangetrokken coördinator zal het werk van de groepen ondersteunen en de vorming van nieuwe initiëren. Het valt niet te ontkennen dat de psycho-sociale disciplines en de eerste lijns gezondheidszorg nog onvoldoende aan bod komen in de zojuist beschreven opzet. Het excuus geld-en tijdgebrek rechtvaardigt dit in onvoldoende mate. Het opnemen van deze disciplines in oncologische werkgroepen acht ik noodzakelijk voor het: verwezenlijken van een der belangrijkste doelstellingen van een integraal kankercentrum, namelijk het zo dicht mogelijk bij de kankerpatiënt brengen van een optimale zorg. Naar aanleiding van hetgeen ik eerder heb opgemerkt over de interactie van chemotherapie en radiotherapie, wil ik graag enkele gedachten wijden aan de klinische oncologie. Waar radiotherapeut en medisch oncoloog, chemotherapeut, samenwerken in een structuur die als klinische oncologie wordt aangeduid, ontstaat de beste garantie voor een optimale behandeling van de kankerpatiennt en vooral van die zieke mens waar uitzaaiïngen van het gezwel zijn opgetreden of moeten worden aangenomen. Hierbij wil ik niet te kort: doen aan de oncologische chirurgie, ofschoon de klinische bijdrage van deze discipline in de laatst decennia meer ligt op technische vervolmaking dan op nieuwe toepassingen.

De laatste jaren worden met toenemend succes patiënten behandeld door een combinatie var radiotherapie en chemotherapie. In het ene geval zal met chemotherapie worden begonnen, in het andere geval eerst worden bestraald. Ook gaat soms de voorkeur uit maar een gecombineerde behandeling. Ongeacht de volgorde van de geschetste combinatie kunnen sterkere effecten op het normale weefsel optreden dan dit het geval zou zijn als men alleen chemotherapie dan wel radiotherapie zou geven. Hoewel de radiobiologie ons enig inzicht heeft verschaft in de mate van deze versterking is deze kennis voor de klinische situatie nog niet toepasbaar. 
Voor het afwegen wan de voor-en nadelen wan een behandeling is een nauwe samenwerking tussen chirurg, radiotherapeut en medisch oncoloog en wooral tussen beide laatsten, gewenst. Samenwerking die elkaars onmiddelijke nabijheid noodzakelijk maakt. Evenzo geldt dit voor de follow-up. Beoordeling van de toestand van de patiënt en de beslissing een bepaalde behandeling in te stellen mag dan enig uitstel verdragen, voor de patiënt heeft het slechts voordeel als hii door vertegenwoordigers van beide disciplines wordt onderzocht en spoedig te horen krijgt hoe het met zijn kanker staat en wat er aan te doen is. Met anderen is het ook onze ervaring dat de geschetste interactie in de klinische oncologie een effectieve is, waarbij onnodig kostbaar onderzoek wordt vermeden en patiënt en familie dankbaar ziju dat wachten in onzekerheid wordt beperkt. leder ziekenhuisbestuur dat gekozen heeft een radiotherapeutisch instituut of een radiotherapie-afdeling aan zich te binden, dient voorwaarden te scheppen voor een optimale ontwikkeling van de klinische onclogie. Dit is, het zij herhaald, een onafscheidelijke samenwerking tussen radiotherapeut en chemotherapeut.

Itk hoop $\mathrm{u}$ enig inzicht gegeven te hebben in een aantal aspecten van de ontwikkeling van de radiotherapie en u duidelijk gemaakt te hebben hoe de radiotherapeut vanuit zijn discipline tegen problemen van de oncologie aankijkt. Ik ben mij bewust een aantal interessante gebieden van mijn specialisme niet te kunnen noemen. Ik denk hierbij aan de hyperthermie, een ontwikkeling waarbij door verwarming een grotere stralengevoeligheid wordt bereikt. Ik denk tevens aan de brachytherapie, een vorm van behandeling waarbij ingekapselde radio-actieve bronnen in lichaamsholten worden gebracht, woonamelijk bij gynaecologische aandoeningen, dan wel als naalden of draden in het tumorgebied worden geplaatsit, zoals bij gezwellen van de urineblaas, de tong of de borstklier.

Tot slot wil ik stilstaan bij enkele technische aspecten van de radiotherapie in onze regio. Onlangs kwam in Heerlen de nieuwbouw wan het Radiotherapeutisch Instituut Limburg, het R.T.I.L., tot stand en konden een 2 e lineaire versneller en simulator in gebruik worden genomen. Hiermee kwam een einde aan de onverantwoorde situatie waarbij in een regio van 850.000 zielen met éen megavoltvoorziening ruim 1000 nieuwe patiënten per jaar moesten worden bestraald. Op grond van vigerende nomen kan de centrale overheid toestemming verlenen een 3 e megavoltwoorziening aan te schaffen. Voor de locatie van clit bestralingsapparaat dient het Academisch Ziekenhuis Maastricht te worden gekozen. Dit is niet in tegenspraak met de 
opvatting, dat woor sterk gespecialiseerde voorzieningen centralisatie nodig is. Zeker voor de radiotherapie geldt dat het niet alleen om kostbare apparatuur met evenredige bouwkundige voorzieningen gaat, maar vooral om een concentratie van hoog-gekwalificeerde medewerkers. Dat onze voorkeur uitgaat naar Maastricht houdt verband met die vormen wan geavanceerde behandeling van aandoeningen van kwaadaardige aard, waarbij de immuniteit van de patiènt na een totale of partiële lichaamsbestraling zo is afgenomen, dat een vervoer naar Heerlen niet mogelijk is. Aspecten van klinische research en onderwijs vervullen bij dit concept evenzeer een rol. Door de bestralingsplanning en -simulatie vóor de aanvang van de behandeling in het "moederinstituut" te laten plaats vinden, wordt het concept van concentratie gewaarborgd. Voor een optimale organisatie dient de 3 e megavolvoorziening geheel onder beheer van het bestuur van het R.T.I.L. te vallen.

Dames en Heren Studenten in de faculteit wan de geneeskunde en de algemene faculteit van deze universiteit. Ik beschouw deze inaugurele rede voor een belangrijk deel tot u gericht. Met verschillenden van u mocht ik reeds kennis maken en enkelen in het Radiotherapeutisch Instituut ontvangen. Ik stel het op prijs $u$ van het boeiende specialisme radiotherapie zó veel te leren als voor een optimaal functioneren in uw toekomstige professie nodig is.

Het College van Bestuur van de Rijksuniversiteit Limburg dank ik voor het in mij gestelde vertrouwen en de daaruit voortvloeiende medewerking, die tot mijn benoeming tot hoogleraar in de radiotherapie door Hare Majesteit de Koningin heeft geleid. Als radiotherapeut verbonden aan het Radiotherapeutisch instituut Limburg zie ik in deze benoeming een concreet voorbeeld van de basisfilosolie van deze universiteit.

Aan het Radiotherapeutisch Instituut Limburg zou ik een aparte oratie kunnen wijden. U, R.T.I.L.-bestuur, dank ik voor de vrijheid die u mij gaf dié mogelijkheden aan te wenden nodig om het Instituut uit te bouwen tot een behandelingscentrum dat beschikt over moderne apparatuur, die een geavanceerde radiotherapeutische behandeling mogelijk maakt.

U, Dames en Heren Medewerkers dank ik allen voor uw inzet en vriendschap, die mij het werken met $u$ tot een steeds weerkerend genoegen maakt. 
Dames en Heren Leden van de medische faculteit en de algemene faculteit, Dames en Heren Collegae in de regio.

Aan de vriendschappelijke en stimulerende samenwerking, die ik de fatste jaren met u mocht hebben, het zij bij verschillende oncologische besprekingen of bij direct contact, het zij in het IKL., hecht ik grote waarde. Deze samenwerking zal rond de gezamenlijke zorg voor de aan ons toevertrouwde patiênten in de toekomst zeker verder groeien.

ik heb gezegd. 